\title{
PRINCIPAL NEW ZEALAND EARTHQUAKES DURING THE YEAR 1973
}

\author{
R. D. Adams*
}

\begin{abstract}
A wide variety of earthquakes occurred in New Zealand during 1973. Many of the larger shocks originated at considerable depth within the Earth, however, and their effects at the surface were not unduly severe. The year's largest earthquake was a deep shock of magnitude 6.7 (Richter Scale), that took place in the early hours of 6 January 1973. The earthquake was about $170 \mathrm{~km}$ deep, and its epicentre was about $20 \mathrm{~km}$ to the west of National Park in the centre of the North Island. As is usual for deep earthquakes, it was felt widely, but without undue severity. The felt area covered the North Island south of a line from Whakatane to Kawhia, and extended as far south as Hokitika and Timaru. The highest intensities were experienced in Taihape and Hawke's Bay, where some chimney damage was reported. A grandfather clock in a homestead near Waipukurau was stopped, this being the first stoppage caused by any earthquake since the major Napier earthquake of 1931. The extensive area over which the earthquake was felt resulted in the Earthquake and War Damage Commission receiving more than 2500 claims, mainly for cracked chimneys, minor cracks in foundations and plaster, and for articles falling from shelves. The amount paid for these claims totalled about $\$ 180,000$.
\end{abstract}

On the morning of 26 March, two other deep shocks were felt widely on both sides of cook Strait. In the Wellington area the shocks caused some concern, but only minor damage was reported. The first earthquake had a magnitude of 5.3 and occurred at a depth of $66 \mathrm{~km}$ beneath D'Urville Island, and the second, 47 minutes later, had a magnitude of 5.4 and a focus $74 \mathrm{~km}$ deep, almost directly beneath Wellington. A further deep earthquake beneath cook Strait occurred on 13 June at a depth of $100 \mathrm{~km}$. It had a magnitude of 5.1 and was felt from Taranaki to Banks Peninsula. Other significant deep shocks beneath the North Island that were reported felt occurred on 15 January beneath the Rotorua region (magnitude 5.5), on 7 March beneath the central North Island (magnitude 5.3), on 15 April beneath Taranaki (magnitude 5.1), on 30 August off East Cape (magnitude 5.5), and on 27 December in the Bay of Plenty (magnitude 5.8).

The largest shallow earthquake of the year occurred early in the morning of 22 February. Its magnitude was 5.7, and its epicentre in Hawke's Bay, about $10 \mathrm{~km}$ southwest of Hastings. It was preceeded by a foreshock of magnitude 4.8 , and was followed after 47 minutes by an aftershock of magnitude 5.1. Within the next day four

* Seismological Observatory, D.S.I.R., Wellington. other aftershocks had magnitudes of 4 or greater. The main shock was felt throughout Hawke's Bay, Manawatu and Wairarapa, and about 800 claims for minor damage were received from the Hastings and Napier areas.

Another sequence of shallow earthquakes took place about $35 \mathrm{~km}$ southwest of Molesworth Station, in Marlborough, late in April. The largest two occurred on 23 April (magnitude 5.2) and 29 April (magnitude 5.1). Road cracking near the epicentre has been interpreted as minor fault movement on the clarence Fault. The felt area of the largest shocks extended into northern Canterbury.

In the Fiordland region, the largest shallow earthquake (magnitude 5.0) occurred near Milford Sound on 23 May. A deeper shock, on 29 January, originated $140 \mathrm{~km}$ beneath the north end of Lake Te Anau and had a magnitude of 5.3 . It was felt widely in the south of the South Island.

A series of small shallow earthquakes occurred near Rotorua on the afternoon of 6 May. The earthquakes were small, the largest being only of magnitude 3.2. The fact that the earthquakes were felt locally may be ascribed to their closeness and shallowness, rather than their size. For similar reasons, a small shallow earthquake (magnitude 2.9) that occurred within $10 \mathrm{~km}$ of the centre of Christchurch on 19 June was reported felt there at moderate intensities.

No significant earthquakes were associated with activity of the central North Island volcanoes, but Mt. Ngauruhoe has been more active than in recent years. Activity that started in November 1972 continued as strong ash eruptions on 1 and 2 January, 1973. Other ash eruptions were most active on 8 September, 26 October, and 7 December. During the December eruption a small ash flow reached halfway down the slope of the mountain. 